Embodied Cognition and the Project of the Bildungsroman: Wilhelm Meister's Apprenticeship and Daniel Deronda

Ben Morgan

Worcester College, Oxford

Abstract: The article uses the example of the European Bildungsroman as represented paradigmatically in Goethe's Wilhelm Meister's Apprenticeship (1795/96) to investigate the effects of reading. Goethe's text is sensitive to the embodied encounters that shape how we relate to the experience of reading, showing the forms of sensuous interaction in which literary reading has its roots. The model of reading presented in Goethe's text is contextualized with reference to debates about fiction circa 1800, but also to research in developmental psychology into the emotional preconditions of an engagement with narrative, and to recent discussions of the socalled paradox of fiction. To explore in more concrete terms the effect of reading Wihelm Meisters Apprenticeship, the article then turns to George Eliot's response in Daniel Deronda (1876). Goethe's novel appeals to the bodies of its characters and its readers. Eliot responds to this appeal by emphasizing that bodily reactions are themselves always shaped by history. However it takes a certain sort of openness, which is learned more through interaction than through fiction, for characters and readers alike to confront the challenges and opportunities that an insight into the embodied nature of larger historical processes presents.

Keywords: embodied cognition, Bildungsroman, George Eliot, Johann Wolfgang von Goethe, paradox of fiction

\title{
1. Debating the Bildungsroman
}

This article will focus on emotional learning as it is portrayed in Goethe's Wilhelm Meister's Apprenticeship (1795/96) and George Eliot's Daniel Deronda (1876), the latter being, as Terence Cave and others have shown, a response to the former (Cave 
2011). ${ }^{1}$ I will be asking what these fictional educations do to, for or with readers. In other words, I'll be addressing the question, "What do novels do?”

Suzanne Keen's Empathy and the Novel has established the benchmark for critical investigation of the moral and emotional effects of reading novels, broadening the focus beyond the literary canon to include popular fiction, and searching for ways of assessing and engaging with the responses of readers themselves (Keen 2007). For if narrative can function as a “moral laboratory,” it is not clear, as Emy Koopman's and Frank Hakemulder's careful review article has shown, whether the effects are produced by the specifically literary aspects of the texts, or by the mere fact of their being stories, high-brow or low-brow, fiction or non-fiction (Koopman and Hakemulder 2015). Moreover, is it the texts themselves, or the discussions and reflections they prompt after reading, that are most transformative for readers (Caracciolo and Van Duuren 2015)? When Keen returns to the subject in a recent essay, she, like Caracciolo and van Duuren, draws attention to processes of reception and the context in which people encounter texts. Whatever potential they contain, "Novels can't be left to do that work on their own" (Keen 2014: 24). "We should not forget the important contribution made by people themselves, around shared fictionreading, as a vital component of the transaction from author to text to reader"(Keen 2014: 24). Keen concludes: "It does not debunk the power of the book or disregard reading to remember the impact of living human beings on one another” (Keen 2014: 31). Reading is something we do together with others, even when we do it on our own.

If we want to understand the processes and practices of literary reading, the Bildungsroman offers a productive point of focus since the genre has from the start had ambitions for its audience. The nineteenth-century critic Karl Morgenstern, who first coined the term Bildungsroman, made this explicit in his definition of the genre: "We may call a novel a Bildungsroman first and foremost on account of its content, because it represents the development of the hero in its beginning and progress to a

I am grateful to Peter Garratt, Sowon Park, Naomi Rokotnitz and Ellen Spolsky for their comments on earlier drafts.

${ }^{1}$ References to the two novels will be given parenthetically in the text. For Goethe's novel, the reference will give book and chapter number, followed by page numbers to the German text and the Princeton University Press translation. For Eliot's novel, the reference will give book and chapter number, followed by a page numbers in Terence Cave's Penguin edition. Full details for all editions are given in the bibliography. 
certain stage of completion, but also, second, because this depiction promotes the development of the reader to a greater extent than any other kind of novel” (Morgenstern 2009: 654-55). A number of late twentieth-, and early twenty-firstcentury critics have noted Morgenstern's definition, and the genre's special attention to the reader (Swales 1978: 12; Moretti 2000: 253; Boes 2012: 5). Indeed, in Boes’s recent discussion, the effect of a Bildungsroman is said to be "performative": like a promise or a marriage ceremony, texts of this genre produce the state of affairs they aspire to, and invite readers to participate in the transformation (Boes 2012: 34). But if these critics share Morgenstern's avowed concern with the reader, they also reproduce his silence about the details of readerly involvement. Morgenstern's lecture doesn't investigate further the effect on the reader to which he draws attention. Nevertheless, his argument gives an interesting, indirect clue as to how such an investigation might be oriented, when it is compared with a text on which Morgenstern drew extensively for his own reading of Wilhelm Meister's Apprenticeship: Christian Gottfried Körner's review of Goethe’s novel, published in Schiller's aesthetic journal Die Horen in 1796. A brief comparison of these two texts will give us a first sense of where an analysis should focus that hopes to understand the educative potential of the Bildungsroman.

The bulk of Körner's review is a discussion of the book's different characters or types. But he finishes by saying there is a limit to how far criticism can uncover a novelist's intentions or the devices that a writer deploys to bring these to life. "[The writer] wants to reveal himself only through his effects. The common reader then cries out 'That can't be invented; a true story must lie behind this' - and the genuine friend of art is suffused by an electric shock [Nur durch seine Wirkungen will er sich verkündigen. Der gemeine Leser ruft aus: 'So etwas erfindet man nicht; hier muß eine wahre Geschichte zum Grunde liegen’ - und den echten Kunstfreund durchdringt ein elektrischer Schlag]” (Gille 1979: 13-14, my translation). For Körner, an electric shock runs through skilled readers when they encounter what a less trained reader would treat as a true story, that is to say, when the truth of the fiction (whatever that might be) strikes them. Morgenstern ignores this aspect of Körner's review. Indeed, he seems to side with Körner's “common reader” insofar as he suggests that Goethe’s autobiography Truth and Poetry shows which "threads” of the writer's life were woven into the novel: "the most lifelike, powerful, and instructive elements of the novel, and indeed of poetry in general, remain those that the poet has himself lived 
and experienced, no matter to what constructs of fancy they may otherwise be tied” (Morgenstern 2009: 658). Two aspects of this difference of opinion are of particular interest for an attempt to understand the effect of a Bildungsroman on its readers. The first is Körner's assumption that it takes training to be the sort of reader who will feel the electric shock. The second is the issue on which the two critics agree. For Morgenstern as for Körner, the transformative effect of novels depends on the sense of reality that they convey. As we become skilled readers of the texts, we also come to connect them with the world beyond the fiction.

The early reception of Wilhelm Meister's Apprenticeship thus confirms the view that novels do things to their expert readers (the "electric shock”), but it also vindicates Keen's interest in the shared activities that underpin the effects of fiction: Körner's review took the form of a letter (as indeed did Morgenstern's own first assessment of Goethe's novel, published in 1796) (Gille 1979: 15-19); Morgenstern's definition of the Bildungsroman took the form of a lecture, and the printed text bears all the traces of the original oral address. What a Bildungsroman was or did was established by conversations and debates from the 1790s onwards, a circumstance that Goethe's novel itself foresaw insofar as much of the text is taken up with conversations and disagreements about different forms of art from puppet theatre and circus acts to performances of Hamlet and the genre of the novel.

If Keen's approach reminds us of the importance of the developing discursive context of novel reading, the original debates around the Bildungsroman raise a question that Keen's argument doesn't directly address: how do we become the experienced readers who can feel the "electric shock" of a text's connection to the world beyond the fiction? The work of Maria Nikolajeva has drawn attention to the processes by which novice readers learn to engage more expertly with fictional worlds, in part by the very process of reading itself, especially books aimed at readers who don't yet have the cognitive, emotional and literary skills of an adult (Nikolajeva 2014: 19). The recognition that reading is a skill that has to be developed if readers are to be touched is a useful addition to a cognitive literary criticism since it reminds us of an insight that has long been part of neuroscientific debates on empathy. One possible explanation of the powerful effect of fiction is that it mobilizes our visceral reactions, causing us to resonate with the experience of the fictional characters we read about (Oatley 2011: 113). I will return later to some of the debates prompted by our immersive involvement with fiction. At this point, I want first to note how studies 
suggest that affective mirroring is at some level a learned behavior. Whatever the shared somatic underpinnings of empathy or of the reading experience, sensorimotor resonance becomes meaningful only in a social context (de Vignemont and Singer 2006). We learn to be immersively engaged, just as we learn to be a "friend of art" rather than just a common reader.

A reading of Goethe's novel can add a further aspect to the debate, since the text raises the question of whether being an expert reader is enough, prefiguring a question that Joseph Appleyard asks in his investigation of the process of Becoming a Reader: the question as to "the kind of readers we will be and the uses to which we will put our reading” (Appleyard 1991: 19). In this article, I will be following up Goethe's interrogation of the uses and limits of reading, and investigating how his novel reflects on, promotes and inhibits our bodily engagement with texts. To start answering the question of how a reader might be transformed by this somatic address, I turn in the second half of the argument to an analysis of one historical example of an engagement with Goethe's text: Eliot's Daniel Deronda. Eliot's novel situates the sympathetically resonating body of character and reader alike in the wider historical context that shapes and constrains their resonance, while showing at the same time the vulnerability, limitations and fallibility of their sympathy.

\section{Reading with Mignon}

A brief episode from Wilhelm Meister's Apprenticeship illustrates the medium and the scope of the book's educative project. The scene comes in the latter part of the novel, just before Wilhelm's official introduction to the Fellowship of the Tower, a quasimasonic group that, unbeknownst to him, has been guiding his development. Wilhelm returns to his theatre troupe having delivered a letter on behalf of the dead Aurelie (who had played Ophelia to his Hamlet), and finds Felix, the toddler whom Aurelie adopted, being read to by Mignon, the girl of unknown Italian origin whom Wilhelm freed, at a cost of 30 taler, from the abusive circus master for whom she had previously performed her tricks of dexterity. "Felix and Mignon were sitting on the floor [...] holding a book. Mignon was reading aloud and Felix repeating the words after her as if he already knew his letters and could really read. [Felix und Mignon saßen (...) auf der Erde; beide hielten ein Buch, und indem Mignon laut las, sagte 
Felix alle Worte nach, als wenn er die Buchstaben kennte, als wenn er auch zu lesen verstünde]” (VII:8, 288/493). ${ }^{2}$

The scene reproduces a situation that Maryanne Wolf, of the Center for Reading and Language Research at Tufts University, suggests is essential to a child's introduction to reading: the physical contact involved in being read to by someone who loves us. "The association between hearing written language and feeling loved provides the best foundation for [emergent literacy]" (Wolf 2007: 83). Part of this process is learning about what Wolf terms "a repertoire of emotions." "Stories and books are a safe place for [a three-year-old] to begin to try these emotions on for herself, and are therefore a potentially powerful contributor to her development. At work here is a reciprocal relationship between emotional development and reading” (Wolf 2007: 85). Learning to read, for Wolf, is thus grounded in the experience of loving interaction, and at the same time is one of the practices through which children understand what it means to be emotionally responsive. Learning to read is thus not so much about acquiring a brain-skill as about participating with increasing competence in forms of social interaction. This is also what Wittgenstein suggests in his Philosophical Investigations when he wonders whether reading is better understood in terms of a hidden, inner process in the brain, or whether the important aspect isn't in fact the context and comportment that goes with it (Wittgenstein 2009: 67-75 [§§15672]). We will know if someone can read because of the way they behave. Moreover, as Wittgenstein reminds us, there isn't one thing called reading: reading is a family of related activities in related contexts (Wittgenstein 2009: 72 [§164]). For Wittgenstein, as for Wolf: reading is a set of shared activities before it is a moment of private recognition. And Wolf adds that it is through these shared activities that we learn how to participate more fully in the process of human attunement.

To understand how this approach can best inform a literary analysis of Goethe's text, we need to reflect for a moment on its methodological status. Wolf's argument makes intuitive sense, and repeats in an empirical idiom what the children's author and educationalist Leila Berg wrote as long ago as the 1970s regarding the emotional and physical environment from which an immersive engagement with books emerges. For Berg, “sensuousness, playfulness, physical intimacy,

2 References to Goethe's novel will be given parenthetically in the text, including the book and chapter number, followed by page numbers to the German text (Goethe 1982) and the Princeton University Press translation (Goethe 1989). 
protectiveness, personal identification” all scaffold and support the developing relation to fiction as they do also the developing relation to language (Berg 1977: 2122). Berg's account is based on her experience as a mother and grandmother and as an author of books for children, rather than on experiment and quantitative analysis. However, looking at the footnotes to Wolf's text (Wolf 2007: 255), it turns out that her claims about the role of a loving environment are not supported by empirical studies any more than Berg's. They are, rather, the anecdotal summary of her experiences working with children. Wittgenstein's analysis of reading is similarly based on introspection and observation. What, then, is the evidence for the idea that the preconditions of learning to read are the affective, bodily interactions between child and carer - the tickle games, for instance, that, for Berg, constitute a child's first experience of stories (Berg 1977: 4)?

An approach such as Wolf's in indebted to Lev Vygotsky and the experiments that he conducted in Soviet Russian in the early 1930s to show that a child's ability to think and solve problems develops by internalizing the conversations he or she has had collaborating with grown-ups (Vygotsky 2012). Following in Vygotsky's footsteps, there is much research to show how the child's developing understanding of other people is nurtured and supported by conversations with carers about what others think and feel (Slaughter 2015). Indeed, there are studies of the importance of such conversations specifically while a child is being read to (Rollo and Sulla 2016). Nevertheless, these investigations of mind-talk and other forms of interaction don't in themselves support the claim made by both Wolf and Berg that it is the attuned emotional quality of the interaction, rather than the subject matter, that makes the difference - for instance, Mignon and Felix holding the book together while Felix plays at reading. Indeed, one often-cited study suggests that speech trumps loving interaction, that a mother talking about mental states is a better predictor of a child's developing social understanding than a secure attachment between mother and child (Meins et al. 2002). Nevertheless, a more recent longitudinal study has demonstrated the importance of "high emotional connectedness" between carer and child for the child's developing ability to interact with others (Licata, Kristen, and Sodian 2016). If we follow this more recent study, we still need to make the step from emotional connection to literary reading and the idea that our engagement with stories arises from, and is importantly shaped by, the first experiences of emotional attunement. 
Colwyn Trevarthen and his colleagues and students have been studying the emotional synchrony between mother and child for almost forty years (Trevarthen 1979). In a recent overview of his findings, Trevarthen makes explicit the connection between the first experiences of attunement and child's growing participation in culture: "human motivation for acquiring cultural meaning grows from taking part with others, imitatively and emotionally, in stories of being alive with a human body" (Trevarthen 2011: 76). Attuned participation is the key to human meaning. Berg would agree (Berg 1977: 20). Nevertheless, a methodological question remains as to how we demonstrate the connection between emotional involvement and the participation in the process of cultural meaning. Who assesses the participation and with what criteria? Doesn't the assessor him- or herself need already to be attuned and participating, already part of the process of meaningful cultural behavior to recognize that participation is taking place? In that case, Wolf, Wittgenstein and Berg's assessments have a similar status to that of the members of Trevarthen's research team evaluating the video material of mothers interacting with their children. We evaluate both emotional and cultural interaction as fellow participants.

These arguments point towards the need for what Leonhard Schilbach and his colleagues call a "second-person neuroscience" that acknowledges the importance of emotional engagement and real-time social interaction (Schilbach et al. 2013). They are also important for cultural analyses, insofar as they suggest a continuum, as opposed to a qualitative shift, between literary and scientific evaluation. As we assess interaction, we are all participant-observers, tasked with being flexible and selfcritical and selecting the tools most appropriate to the situation we find ourselves in. This ideal of an imaginative but self-critical engagement with the emotional situation at hand is exactly what Goethe's text thematizes as the scene with Mignon reading, and Felix playing at reading, unfolds.

Wilhelm is greeted not only by Felix and Mignon, but also by Felix's nurse whom Wilhelm now recognizes as the servant of his first love Mariane, only to be told that Felix is in fact his son by Mariane. He starts to read the letter that supposedly confirms this claim, but is overcome with emotion. At this point Felix picks up the letter and insists that Mignon read it to him. So Wilhelm hears the news as it is read to Felix by Mignon and, once again, repeated by Felix as if he himself could read, compelling Wilhelm to listen to everything twice (VII:8, 289/494). What he learns, however, is nothing new. Mignon says she already knew intuitively what Wilhelm 
learns through this affectionate duet, namely that Felix is Wilhelm's son (VII:8, 289/495). Wilhelm thus learns about a human bond he has himself been neglecting through a scene that epitomizes one of the ways in which people learn emotional engagement. He also discovers that he could already have known what he has just found out if he had been more like Mignon, which raises the question of what it would mean to “be like Mignon.” Terence Cave’s study Mignon’s Afterlives gives an account of the many different things Mignon signified for nineteenth-century readers (Cave 2011). For the moment, it suffices to say that she is a figure of remarkable physical dexterity, whose song articulates a deep sense of longing, and who wants to learn but also knows when she has learned enough to perform life's tasks of loving and mourning (VII:8, 299/511). Thus, in the re-enactment of what could be called the "scene of reading," Wilhelm discovers only what a more loving and physically aware individual might already have known. For Goethe, this intuitive knowledge needn't be a magical insight into what we would now confirm by a genetic paternity test, since paternity, in this novel, is a question of commitment rather than of genes. Later in the novel, a character acknowledges a child as his, even though it is far from clear whether the child has been fathered by him or by Wilhelm, announcing: "Fatherhood rests only on conviction; I am convinced, therefore I am the father [Die Vaterschaft beruht überhaupt nur auf der Überzeugung; ich bin überzeugt, und also bin ich Vater]” (VIII:6, 342/586). Had he been more like Mignon, Wilhelm could have committed sooner to the social relation in which he was already involved regardless of any underlying genetic tie.

Goethe's text thus reminds us of the way many people learn to read, and that reading also means interacting. At the same time, it introduces the idea that the habits we learn may not necessarily be good ones: we might learn to be as obtuse as Wilhelm sometimes is. Jean Lave and Etienne Wenger have argued that learning always involves more than theoretical content (Lave and Wenger 1991). We learn in specific situations, and imitate the behaviors of the "community of practice" in which we learn even as we absorb the explicit lessons. Learning to read will always also involve experiences with forms of emotional interaction, but the habits we gain in the process may be to neglect, misread, or be baffled by the emotions of others, as much as to be attuned to them. In Goethe's novel, Aurelie points out that Wilhelm's brilliant understanding of literary character curiously does not extend to the people he actually lives with (IV:16, 153/266-67). An astute use of language that remains indifferent to 
its bodily substrate is threatening to Aurelie for it leads to false promises, and she herself bears the scars of such disembodied words. So when Wilhelm swears never to make false promises in love, she reinforces the lesson by slicing into the palm of his hand with her dagger (IV:19, 168/291-92). For Aurelie, our linguistic interactions are grounded in our bodily behavior; but this is a lesson we need in some situations to relearn, for it is possible to acquire the behavior of mistreating and ignoring bodily interaction as much as that of nurturing or respecting it.

To ground reading in bodily interaction in this manner raises a question about fiction itself. Do we in the end privilege real relations over their fictional counterparts if we insist on the shared behavior from which language, and by extension literary texts, emerge? Such was the concern of the German Romantic writer Novalis when he re-read Goethe's novel in 1799, concluding that anyone who properly takes to heart the development traced in the book will stop reading novels altogether. ${ }^{3}$ Certainly, Wilhelm's progress takes him beyond the literary figures he was so adept at interpreting to an engagement with the world mediated by his interaction with the child, an interaction which, he feels, grants him a clearer understanding of human nature (VIII:1, 308/526). Yet the worry about abolishing fiction is based on a misunderstanding.

In its modern form, this worry has been dubbed the "paradox of fiction.” The debate started in 1975 with an article by Colin Radford and a reply by Michael Weston in response to the question, "How can we be moved by the fate of Anna Karenina?” (Radford and Weston 1975). Radford's article tries to understand how we can be so stirred by characters whom we know to be mere fictions: "I am left with the conclusion that our being moved in certain ways by works of art, though very 'natural' to us and in that way only too intelligible, involves us in inconsistency and so incoherence” (Radford and Weston 1975: 78). Radford and his successors in the debate are grappling with the "electric shock” noted by Körner when a trained reader is struck by the truth of a fiction. Some later commentators insist on the qualitative difference between normal emotions and those prompted by works of art (Walton 1978; Stock 2014). Others return to Radford's formulations to point out logical flaws and so make the idea that there is a "paradox" of fiction disappear (Matravers 2014), or to set out the resolvable problems in the underlying account of emotional reactions

\footnotetext{
3 “Wer ihn recht zu Herzen nimmt, liest keinen Roman mehr." "Fragmente und Studien 1799-1800”, (Schulz 1981: 546).
} 
(Cova and Teroni 2016). But Radford's insistence on being puzzled by our reaction to literary characters, when combined with the wider account of reading fiction that he gives, offer a more helpful account of the experience of literary emotion than either the insistence that the "emotion-like responses" (Stock 2014: 205) of readers to literature aren't emotions, or the suggestion that the problem doesn't exist (Matravers 2014: 102). Radford registers the way engaging with fiction can interfere with our existing beliefs: his response to Anna Karenina troubles him. At the same time, his discussion gives a revealing picture of the habits that underpin this unease. He suggests that crying at imagined situations is “unmanly” (Radford and Weston 1975: 70), and that children find it difficult to differentiate between fiction and reality in a way that adults don't (Radford and Weston 1975: 71). He admits that many people don't relate to fiction in the way he is describing it: they either don't read, or find reading boring (Radford and Weston 1975: 72). In other words, being moved by fiction, for Radcliffe, is an acquired taste, a skill some people learn as they grow up, which at the same time can prompt behavior that challenges social norms (crying for the "wrong" reason). It is a habit that can take us out of the comfort zone of our own expectations, and produce forms of "inconsistency" and "incoherence."

We are taken beyond our habits in part by the visceral power of the literary text. A recent empirical investigation of reactions to fiction found that subjects reported being less intensely moved by fictional than by non-fictional material, but that physiological measures showed that the levels of visceral arousal were in fact the same for both. The contextual information that they were being moved by fiction prompted a modulation of their emotional response. However, where the material prompted personal associations, this effect was counteracted (Sperduti et al. 2016). A fictional event that provokes a form of recognition will thus have its somatic effect on us, puzzling us with a reaction that seems surprising in the circumstances.

Nevertheless, the puzzlement is all part of the process of having acquired the skill of interacting with fiction, and relating it to our own lives. Literature can be unsettling but not because fiction is a paradox: seeing a literary character as a person is no more paradoxical than seeing a lump of metal on a table as a fork, or a spherical piece of leather crossing a line as a goal. It's a form of learned behavior, grounded in bodily responses, that is inculcated in some of us as we join the stream of a culture's behavior and that, with practice, becomes automatic. Because it is learned, it can't be taken for granted, but must be nurtured, lest we acquire unhelpful versions of the skill. 
But by the same token, because it is learned, it is integrated into forms of human culture. It does not lose its effect due to being situated alongside other forms of human interaction.

As Novalis noted, the puzzling effect of a literary text might entail being taken beyond our habitual way of relating to fiction itself. Goethe's novel contains different models of aesthetic interaction, some of which tie art to behavior beyond the aesthetic sphere while others defend a version of aesthetic autonomy. Wilhelm is counselled by the stranger he meets at the end of Part I of the book to stop expecting his own inclinations to be confirmed by works of art (I:17, 70/38). In the discussion of aesthetics in the final part, the same figure, whom we by this point know to be the Abbé, sees learning to respond to works of art as an exercise in flexibility and selfcontrol, as we master the techniques of uncoupling art from our emotional expectations (VIII:7, 600-01/351). Yet one of his interlocutors, Jarno, is dubious that actual human beings will ever live up to the Abbé's high standards: people will inevitably take their emotions and moral reactions with them into the theatre (VIII:7, 601-02/351-52). Nor is this necessarily a problem. The novel itself wants to touch the chords of familiar emotions, as when Mignon and the old Harpist together sing, "Only they know my pain/ Who know my yearning! [Nur wer die Sehnsucht kennt/Weiß, was ich leide!]” (IV:11, 251/142). The very fact this song has been set to music by so many different composers confirms the resonance of the appeal. At the same time, the narrative is frequently ironic: we see Wilhelm and others making mistakes, misconstruing situations, and being too self-involved. The novel draws on emotions, and simultaneously subjects them to scrutiny, practising exactly the kind of critical participation that we have seen constitutes a form of evaluation open to those already engaged in the practice of human attunement. Given this nuanced approach, the Abbé's comments on flexibility and self-control might be re-stated in vein of a Nietzschean perspectivism: not giving up emotional responses, so much as nurturing them so as to be able skilfully to deploy them. ${ }^{4}$

But perhaps even Nietzschean perspectivism imagines too much control, too much distance from the situations that characters and readers encounter. Again, the novel itself pulls in different directions on this question. Wilhelm is taught to engage more fully with the relationships in which he's already involved, but the process of

\footnotetext{
${ }^{4}$ Nietzsche praises “das Vermögen, sein Für und Wider in der Gewalt zu haben und aus- und einzuhängen” (Nietzsche 1988: 364).
} 
caring for a son also instructs him in humility, as he realizes that he learns more from the child than he teaches in return. Despite Wilhelm's admonitions, the child retains many of the habits he had already acquired, whether Wihelm finds them irritating like forgetting to close doors and drinking directly from the bottle, or more endearing, like sitting down in a corner with a book, even though he can't yet read, and declaring "I must study this learned stuff [Ich muß das gelehrte Zeug studieren]” (VIII:1, 528/308). This last example shows again Goethe’s sensitivity to the activities and behavioral norms that underpin our relation to literary texts, as well as his understanding of the child's awareness that language and reading, like physical interaction are "a way of enriching the bond between yourself and someone else" (Berg 1977: 20). The insistence on drinking from the bottle, meanwhile, is of particular importance because it saves the child's life in the last chapter of the book. It prevents him from imbibing the huge dose of opium that another character has added to a glass of almond milk: "His bad habit saved him [Seine Unart hat ihn gerettet]" (VIII:10, 633/370). If Felix teaches Wilhelm the importance of human interaction, he also exemplifies a life-giving resistance to education.

This resistance to cultural norms needs to be taken into account in a wider reading of the book. Wilhelm himself, as Kathryn Edmunds noted in her psychoanalytic reading of the text, is hesitant to include, in the self-understanding he finally arrives at, all that he has learned through sensuous experience (Edmunds 1996). But the text as a whole is more tolerant of bodily mediums of human interaction. ${ }^{5}$ In addition to the life-saving effects of unruly behavior, and the lesson cut literally into Wilhelm's flesh by Aurelie, the interaction, sexualized to varying degrees, that Wilhelm has with Mariane, with the Countess, with the actress Philene, and also with Mignon, are all part of the process by which he is transformed as he encounters people and does things with them. Felix himself survives as the testimony that sex is a good thing - the felicitous offspring of the tangle of desire that Wilhelm, Mariane and the other man, Norberg, were caught in at the beginning of the novel. Even if one line of development in the book is towards renunciation, and towards a

\footnotetext{
${ }^{5}$ Elisabeth Krimmer is less optimistic. "Bildung in Wilhelm Meisters Lehrjahre is not to be defined as the moral and psychological development of an individual, but as an ongoing process of renunciation that is crowned by the successful integration into society of men whose homosocial bond guarantees patrilineal descent and hence societal order" (Krimmer 2004: 268).
} 
disengagement of art from life, the book does not contain or control all the other elements. ${ }^{6}$

The body thus remains a fundamental resource in the novel. Wilhelm's development arises from a corporeal in addition to a conscious engagement with human relationships: he makes mistakes, people get hurt, he doesn’t always know what he does, and, indeed, he finally gives up the desire to control his own destiny and yields to the guidance of others (VIII:10, 623/364). However, neither in the plot, nor in the form of the book, is the body tidied away. It is partly mobilized, and partly yielded to; sometimes compliant, sometimes resistant, it remains the site of an ongoing, dynamic negotiation - an unfinished project. As Nicholas Boyle argues in his detailed account of the open-ended nature of the text: "Goethe is still undecided whether he is undecided” (Boyle 2000: 422). Nevertheless, the book does commit to bodily involvement.

This account of the ways Wilhelm Meister's Apprenticeship appeals to the body even as it regiments it raises the question of how the reader's body responds to the bodies in the text. What does the body do for and with its readers? How does it convey the "electric shock" that Körner diagnosed? What we have seen from the book's reflection on reading as a shared social process, is that different readers will react according to the habits of emotional attunement they are themselves in the process of learning, or have already assimilated. The book acts less as a trigger, and more as an opportunity that can produce differing results arising from the competing impulses in the book: on the one hand to leave embodied knowledge behind and, on the other, to acknowledge corporeal resources.

Are there ways in which the text nevertheless promotes one response rather than the other? And must we, in fact, choose between them? The way we answer this question will depend in part on our model of reading. If reading is taken to be a highlevel cognitive computation, then the bodily impact of reading will seem small. Whatever somatic elements there are in the book, they will only ever be represented, computationally mediated images of embodiment - the "emotion-like responses" (Stock 2014: 205) of Kathleen Stock’s defence of the paradox of fiction. But I have

${ }^{6}$ As Terence Cave has noted in the case of Mignon and the reactions she sparked (Cave 2011). In a similar vein: Schiller, as one of the first readers of the text, thought Mariane's death to be unnecessary: she is, in his view, killed by the demands of the novel not by those of nature; the form is imposed on material that resists it (Schiller to Goethe, $2^{\text {nd }}$ July 1796) (Bahr 2000: 268). 
been elaborating a different model of reading, derived from Goethe's own observation of the scene of reading, for which our encounters with literary texts are human encounters, enabled and determined by our bodily commitments to others. In Wilhelm's account of his progress towards the theatre, the puppets that inspired him as a boy are stored in his parents' pantry, associated with the sensual pleasures of prunes, aromatic spices, dried apples and preserved pomegranate skins (I:7, 17/7-8). The Abbé's model of aesthetic experience strives to transcend the sensuousness of art. But in its open-endedness, the novel itself remains committed to more embodied responses.

If reading is always to some degree a somatic process, a literary response will nevertheless not necessarily celebrate human physicality. It will, rather, elaborate an attitude to embodiment: a way of participating in the physicality of shared human activity that may try to keep the body at bay as much as to acknowledge or honour it. Wittgenstein insisted that there isn't a single practice called reading; rather, there are a number of activities that resemble each other without being identical. Similarly, there won't be a single reading of Goethe's text but different ways of taking up the opportunities it affords. Terence Cave has shown how European culture of the nineteenth and twentieth centuries contains an archive of responses to the text: readings, re-writings, song settings, and adaptations that can give us a sense of how readers negotiated the challenge of the text, but that also confirm how the bodily effect of a novel can't be detached from the activities and discourses it provokes (Cave 2011). In the last part of my argument, I want to look at one response in particular: that of George Eliot, who takes up aspects of Goethe's novel that have been central to my account of the visceral effects of reading. Eliot is acutely aware both of the way social context frames and constrains opportunities for affective engagement with others, and of the way such engagement is always a step into the unknown, precisely because it takes us beyond the comfort zone of our expectations and leaves us with the unfolding, bodily encounter itself. In Franco Moretti's account, Daniel Deronda represents an ambivalent example of the Bildungsroman, written when the historical context that made the genre meaningful no longer existed (Moretti 2000: 227). For Tobias Boes, the novel re-thinks the place of the Bildungsroman by engaging with the questions of nationalism and asking "how racial difference might affect the process of both individual and collective identity formation in liberal societies” (Boes 2012: 118). My own reading will emphasize the ways in which, in 
Eliot's re-working of the genre of the Bildungsroman, the secure, external position that would allow any character, narrator or reader to finally position themselves in relation to the major historical currents of their age is not available. The novel challenges its readers by the very way it immerses them in the unfolding process of human culture. Fiction, in Eliot's hands, becomes an encounter with the visceral effects of history itself.

\section{The Blush of History}

The brief essay that Eliot published on Wilhelm Meisters Apprenticeship in 1855 deals explicitly with the question of the book's appeal to the body. Eliot values what she calls the "large tolerance of Goethe" and explains how a book can responsibly portray the full range of human behavior: "the novelist may place before us every aspect of human life where there is some twist of love, or endurance, or helplessness to call forth our best sympathies” (Eliot 1990: 309). Eliot can condone the book's frank portrayal of sexual entanglements because of the uplifting aspirations that accompany them. However, she does not directly countenance the idea that we might grow emotionally and spiritually precisely through a full engagement with our embodied existence. Does Eliot's response to Goethe's novel therefore etiolate the very bodily aspect that gives the book its power? Terence Cave reads Daniel Deronda as a "critique of Wilhelm Meister, of its narrative consistency and its morality" (Cave 2011: 152-53). The character of the Jewish singer Mirah, and Deronda's openness to being transformed by his encounter with her can, he suggests, be interpreted as an answer to and correction of Wilhelm's "persistent inability to focus on the moral lives of those around him” and in particular of Mignon (Cave 2011: 147). At the same time, Cave notes that Goethe's novel, taken as a whole, has space for the very impulses it censures and expunges, which is why the rich mixture of elements held together in the figure of Mignon can spawn the complex layering of responses of subsequent readers. Does Eliot's critique demonstrate the same pluralism as Goethe?

One possible answer would be that Eliot is reluctant to consider real bodies, a reluctance most visible to critics in her complete silence about whether Deronda is circumcised, and if he is, why he hasn't noticed - vital information, one would have thought (Chase 1978: 222). But this silence, so loud to later critics, was perhaps not so salient for her contemporaries precisely because they shared with Eliot the same habits of indirection by which bodily existence could be lived even if it could not be 
explicitly addressed (Newton 1981). Rather than accusing Eliot of sharing the euphemistic habits of her age, I think we may look at how her novel introduces a further layer to reflection on the bodily interaction in which culture is necessarily grounded.

One of the controversial elements of the book was Eliot's decision to deny her readers the romantic entanglement that the beginning of the book seems to herald between Gwendolen Harleth and Daniel Deronda, whose eyes meet across the roulette table in a German spa. F. R. Leavis famously suggested that the accompanying plot which traces how Deronda discovers that he is Jewish might simply be abandoned to leave a much better novel called Gwendolen Harleth of which Henry James’s A Portrait of a Lady is the more sentimental re-write (Leavis 1962: 103-04). Quite apart from its apparent anti-Semitism, Leavis's reading misses the whole point of Gwendolen's development, from the "spoiled child" of the first part who "meant to lead" in the tiny sphere in which she moved $(\mathrm{I}: 4,39)$ to the widow who feels the brush of the larger processes of history of which she is also part, and with which Deronda himself is more directly grappling. The narrator explicitly draws attention to the lazy use of language that can feed our sense of importance even as it cushions us from the stark sense of our insignificance: “'Gwendolen will not rest without having the world at her feet,' said Miss Merry, the meek governess: - hyberbolical words which have long come to carry the most moderate meanings; for who has not heard of private persons having the world at their feet in the shape of some half-dozen items of flattering regard generally known in a genteel suburb?” (I:4, 39). In her final meeting with Deronda, in contrast, Gwendolen gains an abrupt sense of what it feels like to encounter the world outside her genteel milieu. For she discovers that the man she longs for has, for all his concern for her, other interests, namely marrying Mirah and travelling to Ottoman Palestine: "she was for the first time feeling the pressure of a vast mysterious movement, for the first time being dislodged from her supremacy in her own world, and getting a sense that her horizon was but a dipping onward of an existence with which her own was revolving” (VIII:69, 804).

Readers are invited to participate in this change of perspective, precisely to the degree that, like Leavis, they hoped for a different novel. Gillian Beer has argued that Daniel Deronda “is a novel about that which does not occur” (Beer 2009: 219). This insight could be reformulated more positively: Daniel Deronda is a novel about things occurring in ways that do not fit predetermined novelistic, or societal, formulae. The 
text mobilizes readers' expectations, derived from experiences of reading other stories, so as to offer them a plot that transforms, displaces and relativizes the desires both of the central characters and of readers themselves rather than being confined by them. Despite Leavis's disgruntlement, the novel seems to have struck many readers as a thrilling journey. As Eliot noted herself in her journal, the strong sales of the book in both America and England, even after the story of Deronda's encounter with Judaism had become a prominent feature of the plot, give "an unmistakable guarantee that the public has been touched" ( $1^{\text {st }}$ December 1876) (Carroll 1971: 365). A balanced review written by R. H. Hutton for the Spectator gives us a more precise sense of how the text worked on a sensitive reader. Hutton criticizes the portrayal of the Jewish characters as insufficiently vivid, and the epigraphs Eliot wrote for many of the chapters as too artificial, but he accords special praise to the interactions between Gwendolen and Deronda, and in particular to the scene in which Gwendolen finally realizes the narrowness of what she took to be her world: "There is a subtlety in the relations of the two,--relations which have never in any way been those of passion,- - and a delicacy in the painting both of her forlorn sinking heart and of his natural tenderness for her, which seem to us among the most original conceptions of modern literature."7

Hutton's review draws attention to an aspect of our bodily interaction that my discussion of Goethe’s novel didn’t particularly emphasize: a visceral connection between the two characters that cannot be explained as simply "passion.” More importantly, Eliot's attention to this non-sexual interaction accompanies her evident concern to understand the point at which individuals engage with the wider history in which they participate. This relation, for Eliot, is not merely intellectual. In her essay on the writings of the German cultural historian Wilhelm Heinrich von Riehl, Eliot described the everyday, lived relations of people in civil society as "incarnate history"; she suggests our relation to wider cultural patterns is bodily as much as it is conceptual (Eliot 1990: 127). Yet, if we embody history in our everyday life, we don't always know that we do so, and the novel Daniel Deronda charts the course of two characters learning to feel this bodily attachment more directly. For Deronda, this involves a discovery of his parentage: genetics and culture overlap in the inheritance of his Jewishness. But for Gwendolen, too, the encounter with history has bodily

\footnotetext{
${ }^{7}$ R.H. Hutton's review in the Spectator, $9^{\text {th }}$ September 1876, (Carroll 1971: 370).
} 
repercussions. The final moment of realization comes when Deronda reminds her of what she in some sense already knew about his involvement with Mirah and her consumptive brother, since she had interacted more or less directly with all three of them: "A great wave of remembrance passed through Gwendolen and spread as a deep, painful flush over face and neck” (VIII:69, 804). Gwendolen’s understanding is a physical reaction: a discomforting blush. The reaction is social through and through, a response to a past interaction recast in the light of a present one - the involuntary letting through of knowledge she had previously overlooked. Gwendolen's blush is historic in the fullest sense of the word; it marks a major shift, and is, at the same time, the mark of her bodily surrender to the wider concatenations of social interaction.

The "electric shock" that Wilhelm Meister's Apprenticeship was said by Körner to produce in the trained reader has been transformed into a discomforting blush for a character whose problem is precisely that her literary training has not prepared her for her encounter with the unpredictable unfolding of her life, and in particular with the man she will marry, Grandcourt (II:13, 137). Just as Aurelie observed that being an expert reader did not necessarily help Wilhelm, so Eliot's narrative presents characters whom reading has not properly prepared for life. Literary models no more allow Grandcourt's assistant Lush to understand his employer than they allow Gwendolen to understand her future husband (III:25, 281-82).

But even where the acquisition of learning does seem to have positive effects, as is the case with Mirah's consumptive brother, Mordecai, steeped in the Jewish tradition and with a "yearning for transmission” (V:38, 472), the result is nevertheless disconcerting for other characters, and also for the reader. Deronda notes how the conviction of the genuine prophet and that of the dreamer can barely be told apart; there is, he observes, a "family likeness among the heirs of enthusiasm" (VI:41, 510) that makes Mordecai's faith unreadable. To readers post-1948 and the establishment of the modern state of Israel, the puzzle that the figure of Mordecai, with his protoZionist aspirations, presented in the 1870s is perhaps no longer properly visible. But if we return to David Kaufmann’s sympathetic “appreciation” of Eliot’s engagement with Judaism, the uncertainty of Mordecai’s project is still clear: "the authoress has succeeded in bringing before us, in all its inward, compelling power, and in all its fiery, action-craving impetuosity, no common passion of mankind, well known and easy to understand, but a special sentiment shared by few, strange, and therefore 
incomprehensible to many” (Kaufmann 1878: 40). A similar idea is expressed, albeit more critically, by the character Constantius in Henry James satirical dialogue about the novel when he complains, “I don’t understand more than half of Mordecai's rhapsodies, and I don't perceive exactly what practical steps could be taken. Deronda could go about and talk with clever Jews — not an unpleasant life” (Carroll 1971: 423). Deronda is, on the one hand, able to confront his historical situation in a way the novel emphasizes is not available to a young woman like Gwendolen, "busy with her small inferences of the way in which he could make her life pleasant” (II:11, 124). On the other hand, the encounter with history does not bring certainty, and we do not follow Daniel and Mirah to the East. As Amanda Anderson points out, Deronda's discovery of his Jewishness does not fix, it rather "awakens" his mind, leading to "an open-ended process of argumentation” (Anderson 1997: 48). Readers are themselves involved in this open-ended process insofar as the expectations they may have had are disappointed, while others are generated. To argue thus is, on one level, to make a point about literary habits. But as Gillian Beer has argued (Beer 2009: 191-93), it is also the way in which Eliot's novel grapples with the insight that, for individuals who are “incarnate history," our visceral engagement with our environment does not necessarily bring certainty. In this, Eliot follows Goethe's novel, which freezes its final tableau before Wilhelm is united with the woman he has come to realize he loves (Boyle 2000: 391-92). But Eliot also moves beyond Goethe's text, to which she is responding, by foregrounding her awareness that the appeal to the body is always also an acknowledgment of the vulnerability to wider social processes. Eliot adds to Wihelm Meister's Apprenticeship the knowledge of historical finitude.

In Wilhelm Meister's Apprenticeship , we saw a form of learning and emotional growth grounded in a body that finally resisted regimentation, a resistance tolerated by the pluralistic openness that no machinations of the Fellowship of the Tower could contain. But the question remained as to how readers might themselves be involved in such a process of growth. On the one hand, they participate insofar as reading is itself an embodied activity: reading means interacting, not just with texts but with a stream of situated readers past present and future. On the other hand, a response like Eliot's draws attention to the historicity of this encounter. The appeal to an unregimented body, and to its affective resources, is always also an encounter with wider historical patterns. We may, like Leavis, find it unpleasant to encounter these wider patterns; we may, like Gwendolyn, be reluctant to admit that our bodily 
experience is neither merely personal nor blandly universal. But one of Eliot's achievements is to demonstrate that it takes a visceral engagement to break our habits, and that it is through the body that we transform how we live our relation to ourselves, and indeed to others. We can't simply think about history. It must flood through us as a blush; something we cannot hide from ourselves or from others. Eliot's novel suggests the physical effort of this encounter, using words to mark the point at which we return to the bodily interactions: "[Gwendolen] could not finish. It was not that she was sobbing, but that the intense effort with which she spoke made her tremulous. The burthen of that difficult rectitude towards him was a weight her frame tottered under” (VIII:69, 806).

To conclude: my argument started with the question of what novels do. To begin answering it, we needed first to see what is really doing the work in the literary encounter. Following Goethe's own lead in his presentation of Felix and Mignon reading together, I suggested that the powerful somatic effects of reading are shaped and supported by the early sensuous and communicative interactions from which the habits of literacy develop. But if reading is always in some sense bodily, the skills we have learned may be used to constrain and manage affective interaction as much as to nurture it. The judgment as to whether we're promoting or prohibiting will always be made fallibly from inside the process of interacting itself. Goethe's novel, in its pluralism, challenges readers to take responsibility for their own embodied response. But Eliot suggests that our opportunities for engagement may already be limited in advance. Where Felix and Mignon can resist education, Gwendolen’s horizons, as well as the tools at her disposal, are determined by the context in which she finds herself. Nevertheless, both she and Daniel, in their developing non-encounter, come to a sense of the wider concatenations in which they participated. One answer to the question of what novels do, therefore, is that they can involve the reader in a lived sense of their own involvement. But this isn't something that can be taken for granted. For Wilhelm, Daniel and Gwendolen alike, their progress is accompanied by an engagement with a range of cultural artefacts. But it is less the artefacts that make the difference than the willingness to feel answerable to someone, and to be honest with oneself when expectations are disappointed, or opportunities arise. The novels themselves can mobilize readers' bodies and offer a sense of our visceral participation in historical processes. But the feeling of being answerable and open to disappointment — or indeed to delight—is a skill we learn through the process of 
reading with others: "Novels can't be left to do that work on their own” (Keen 2014: 24).

\section{References}

Anderson, Amanda.

1997 “George Eliot and the Jewish Question,” The Yale Journal of Criticism 10: 39-61.

Appleyard, Joseph Albert 1991 Becoming a Reader: The Experience of Fiction from Childhood to Adulthood (Cambridge: Cambridge University Press).

Bahr, Erhard, ed. 2000 Johann Wolfgang Goethe: Wilhelm Meisters Lehrjahre (Stuttgart, Reclam).

Beer, Gillian 2009 Darwin's Plots: Evolutionary Narrative in Darwin, George Eliot, and Nineteenth-Century Fiction (Cambridge: Cambridge University Press).

Berg, Leila 1977 Reading and Loving (London: Routledge \& Kegan Paul).

Boes, Tobias 2012 Formative Fictions: Nationalism, Cosmopolitanism, and the 'Bildungsroman' (Ithaca, NY: Cornell University Press).

Boyle, Nicholas 2000 Revolution and Renunciation (Oxford: Clarendon Press).

Caracciolo, Marco, and Thom Van Duuren 2015 "Changed by Literature? A Critical Review of Psychological Research on the Effects of Reading Fiction,” Interdisciplinary Literary Studies 17: 517-39.

Carroll, David, ed. 1971 George Eliot: The Critical Heritage (London: Routledge \& Kegan Paul).

Cave, Terence 2011 Mignon's Afterlives: Crossing Cultures from Goethe to the Twenty-First Century (Oxford: Oxford University Press).

Chase, Cynthia 1978 "The Decomposition of the Elephants: Double-Reading Daniel Deronda," Publications of the Modern Language Association of America 93.2: 215-27.

Cova, Florian, and Fabrice Teroni 2016 "Is the paradox of fiction soluble in psychology?," Philosophical Psychology 29.6: 1-13. 
de Vignemont, Frederique, and Tania Singer

2006 “The Empathic Brain: How, When, Why?,” Trends in Cognitive Sciences 10: 435-41.

Edmunds, Kathryn R.

1996 “'Ich bin gebildet genug... um zu lieben und zu trauern': Wilhelm Meister's Apprenticeship in Mourning,” The Germanic Review: Literature, Culture, Theory 71: 83-100.

Eliot, George.

1990 Selected Essays, Poems and Other Writings (London: Penguin).

1995 Daniel Deronda, edited by Terence Cave (London: Penguin).

Gille, Klaus F, ed.

1979. Goethes Wilhelm Meister: Zur Rezeptionsgeschichte der Lehr- und

Wanderjahre (Königstein: Athenäum).

Goethe, Johann Wolfgang

1982 Wilhelm Meisters Lehrjahre, edited by Ehrhard Bahr (Stuttgart: Reclam).

1989 Wilhelm Meister's Apprenticeship, tranlsated and edited by Eric A. Blackall

(Princeton: Princeton University Press).

Kaufmann, David

1878 George Eliot and Judaism: An Attempt to Appreciate 'Daniel Deronda'

(Edinburgh: William Blackwood and Sons).

Keen, Suzanne

2007 Empathy and the Novel (Oxford: Oxford University Press).

2014 "Novel Readers and the Empathetic Angel of Our Nature," in Rethinking Empathy through Literature, edited by Meghan Marie Hammond and Sue J. Kim (Abingdon: Routledge).

Koopman, Eva Maria (Emy), and Frank Hakemulder

2015 "Effects of literature on empathy and self-reflection: A theoretical-empirical framework,” Journal of Literary Theory 9: 79-111.

Krimmer, Elisabeth

2004 “Mama’s Baby, Papa’s Maybe: Paternity and Bildung in Goethe’s 'Wilhelm Meisters Lehrjahre,”’ German Quarterly 77.3: 257-77.

Lave, Jean, and Etienne Wenger

1991 Situated Learning: Legitimate Peripheral Participation (Cambridge:

Cambridge University Press).

Leavis, Frank Raymond

1962 The Great Tradition (Harmondsworth: Penguin). 
Licata, Maria, Susanne Kristen, and Beate Sodian

2016 "Mother-Child Interaction as a Cradle of Theory of Mind: The Role of

Maternal Emotional Availability,” Social Development 25: 139-56.

Matravers, Derek

2014 Fiction and Narrative (Oxford: Oxford University Press).

Meins, Elizabeth, Charles Fernyhough, Rachel Wainwright, Mani Das Gupta, Emma Fradley, and Michelle Tuckey

2002 "Maternal Mind-mindedness and Attachment Security as Predictors of

Theory of Mind Understanding,” Child Development 73: 1715-26.

Moretti, Franco

2000 The Way of the World: The Bildungsroman in European Culture (London:

Verso).

Morgenstern, Karl

2009 “On the Nature of the Bildungsroman,” PMLA 124: 647-59.

Newton, Ken M

1981 “Daniel Deronda and Circumcision,” Essays in Criticism 31: 313-27.

Nietzsche, Friedrich

1988 Zur Genealogie der Moral (Munich: Deutscher Taschenbuch Verlag).

Nikolajeva, Maria

2014 Reading for Learning: Cognitive Approaches to Children's Literature

(Amsterdam: John Benjamins).

Oatley, Keith

2011 Such Stuff as Dreams: The Psychology of Fiction (Chichester: Wiley

Blackwell).

Radford, Colin, and Michael Weston

1975 "How Can We Be Moved by the Fate of Anna Karenina?," Proceedings of the Aristotelian Society, Supplementary Volumes 49: 67-93.

Rollo, Dolores, and Francesco Sulla

2016 "Maternal Talk in Cognitive Development: Relations between Psychological Lexicon, Semantic Development, Empathy, and Temperament,” Frontiers in Psychology 7: Article 394, doi: 10.3389/fpsyg.2016.00394.

Schilbach, Leonhard, Bert Timmermans, Vasudevi Reddy, Alan Costall, Gary Bente, Tobias Schlicht, and Kai Vogeley

2013 “Toward a second-person neuroscience,” Behavioral and Brain Sciences, 36: 393-414.

Schulz, Gerhard, ed. 1981 Novalis Werke (Munic: Beck). 
Slaughter, Virginia

2015 "Theory of Mind in Infants and Young Children: A Review," Australian Psychologist 50: 169-72.

Sperduti, Marco, Margherita Arcangeli, Dominique Makowski, Prany Wantzen, Tiziana Zalla, Stéphane Lemaire, Jérôme Dokic, Jérôme Pelletier, and Pascale Piolino 2016 "The Paradox of Fiction: Emotional Response toward Fiction and the Modulatory Role of Self-Relevance,” Acta psychologica 165: 53-59.

Stock, Kathleen 2014 "Physiological Evidence and the Paradox of Fiction," Aesthetics and the Sciences of Mind edited by Gregory Currie, Matthew Kieran, Aaron Meskin and Jon Robson (Oxford: Oxford University Press).

Swales, Martin

1978 The German Bildungsroman from Wieland to Hesse (Princeton: Princeton University Press).

Trevarthen, Colwyn

1979 "Communication and Cooperation in Early Infancy: A Description of Primary Intersubjectivity," in Before Speech: The Beginning of Interpersonal Communication, edited by Margaret Bullowa, 321-47 (Cambridge: Cambridge Univeristy Press).

2011 "The Generation of Human Meaning: How Shared Experience Grows in Infancy," in Joint Attention: New Developments in Psychology, Philosophy of Mind, and Social Neuroscience, edited by Axel Seemann, 73-113 (Cambridge, MA: MIT Press).

Vygotsky, Lev

2012 Thought and Language (Cambridge, MA: MIT Press).

Walton, Kendall L.

1978 “Fearing fictions,” The Journal of Philosophy 75: 5-27.

Wittgenstein, Ludwig. 2009 Philosophische Untersuchungen: Philosophical investigations (Oxford: Wiley-Blackwell).

Wolf, Maryanne 2007 Proust and the Squid: The Story and Science of the Reading Brain (New York: HarperCollins). 